\title{
Nexus between the gendered socio-economic impacts of COVID-19 and climate change: implications for pandemic recovery
}

\author{
Mark M. Akrofi ${ }^{1}$ D $\cdot$ Mudasiru Mahama ${ }^{2}$ D Chinedu M. Nevo $^{3}$ (D)
}

Received: 22 December 2020 / Accepted: 8 July 2021 / Published online: 2 August 2021

(c) The Author(s), under exclusive licence to Springer Nature Switzerland AG 2021

\begin{abstract}
Gender is a critical factor in how people respond to, and recover from major disruptions such as natural disasters or disease outbreaks. Climate-related disasters are known to pose-gender specific problems that disproportionately affect more women than men. Similarly, the COVID-19 pandemic's impacts along gender lines are enormous, with women being the worst-affected. Existing studies have drawn connections between COVID-19 and climate change, with most arguing that responses to the pandemic provide an opportunity to tackle climate change through emission reduction strategies as part of recovery efforts. We introduce a new dimension to this connection by demonstrating that though different phenomena, COVID-19 and climate change are not so dissimilar in terms of their gendered socioeconomic impacts. Through a systematic review of the available literature, we establish a nexus between these impacts, and examine how the gender responses to COVID-19 can be leveraged to address gender-related climate impacts. We find that social protection, labor market, economic, and violence against women measures adopted in response to the pandemic provide a good opportunity to address the gender impacts of climate change as well. However, current COVID-19 gender responses do not incorporate the interconnections between the gender impacts of the pandemic and climate change. Adopting a nexus approach could help to leverage COVID-19 responses to address the gendered socioeconomic impacts of both crises.
\end{abstract}

Keywords Coronavirus · Climate change $\cdot$ Gender equality $\cdot$ Sustainability Vulnerability

Mark M. Akrofi

macakrofi@gmail.com

Extended author information available on the last page of the article 


\section{Introduction}

The COVID-19 pandemic continues to affect various facets of society amidst the significant challenges already posed by the climate crisis. While the impacts of these two problems are experienced on a societal scale, they have exposed and exacerbated existing inequalities in society and, in so doing, tend to affect some groups of people more than others (Blundell et al. 2020; Eastin 2018). Women and girls, in particular, have been identified to be the worst affected in terms of the gendered impacts of climate change since its socioeconomic impacts pose gender-specific risks which disproportionately affect more women than men (Abbasi et al. 2019; Eastin 2018; Goodrich et al. 2019). It is widely acknowledged that women's triple burden in the gender division of labor-productive, reproductive, and community roles-exacerbates their vulnerabilities in times of natural disasters, wars, or disease outbreaks (Bradshaw 2015; Sanaul and Mondal 2014). This situation is attributed to the additional burden that women carry in such disruptions, which add to their pre-disaster vulnerabilities (McLaren et al. 2020). The COVID-19 outbreak has reaffirmed this standpoint as its socioeconomic impacts have also been identified to disproportionately affect more women than men (Alon et al. 2020; Chauhan 2020).

The pandemic has placed additional responsibility on women, and it is deepening existing gender inequalities. COVID-19 induced lockdowns and the closure of schools and daycare centers, for instance, have increased the caregiving burden of women, reduced their gainful employment times, and also exposed them to heightened domestic violence (Alon et al. 2020; Collins et al. 2020; McLaren et al. 2020). This current situation is consistent with past studies which also found that disasters or disease outbreaks increase women's workload and decrease their productive hours (Bradshaw 2015; Stemple et al. 2016). Similarly, in many developing countries, women (especially in rural and peri-urban areas) tend to spend longer periods in search of water and fuelwood due to climate change. Consequently, their productive hours are reduced and the extended periods spent on doing unpaid care work has further deepened inequalities between women and men (Flatø et al. 2017; Nabalamba et al. 2011). Gender concerns in responding to disasters or disruptions are critical to ensure that new opportunities are created, and vulnerable groups are empowered to recover and engage equally and equitably in socioeconomic and political spheres (Leckie 2016; Momsen 2019).

In line with the above assertion, several studies have been carried out, with many focusing on identifying the gendered impacts of climate change (Abbasi et al. 2019; Bhadwal et al. 2019; Eastin 2018; Goli et al. 2020; Goodrich et al. 2019) and COVID-19 (Alon et al. 2020; Blundell et al. 2020; Collins et al. 2020; McLaren et al. 2020). Several studies that draw linkages between climate change and COVID-19 have also emerged. In their article-a tale of two crises: COVID19 and climate-Markard and Rosembloom (2020) argued that resources being amassed by governments in response to the COVID-19 pandemic could be leveraged to accelerate the decline of carbon-intensive industries and practices and to drive low carbon innovation. Other studies pointed out that the pandemic has 
yielded some benefits, though short-term, for the fight against climate change through reduced environmental pollution (Arora et al. 2020; Muhammad et al. 2020; Saadat et al. 2020) and reduced carbon emissions (Le Quéré et al. 2020; Paital 2020; Rugani and Caro 2020). Notably, such connections between climate change and COVID-19 do not exist in terms of their socioeconomic impacts. The relationship between the two is also depicted so that COVID-19 is seen as a temporary phenomenon while climate change is seen as a long-term problem (Markard and Rosenbloom 2020; Sovacool et al. 2020).

In this article, we argue that while COVID-19 may be temporary, some of its socioeconomic impacts will have lasting effects and, thus, need to be addressed from a long-term perspective. The gendered socioeconomic impacts of the pandemic, for instance, are something that scholars have already identified to be a long-term phenomenon (McLaren et al. 2020). Hence, we attempt to establish a nexus between COVID-19 and climate change regarding their gendered socioeconomic impacts. We argue that such a nexus is essential for formulating policies that can address genderspecific problems caused by both climate change and the COVID-19, especially in developing countries where these impacts are severe, and resources to address them are limited. Addressing gender-related problems of climate change and COVID-19 separately could result in fragmentation of already scarce resources, resulting in inefficient and ineffective resource use. The main questions we attempt to answer are: (1)what is the nexus between the gendered socio-economic impacts of climate change and COVID-19? and (2) how can COVID-19 gender responses be leveraged to address climate-induced gender impacts?

\section{Methods}

The four steps (identification, screening, eligibility, and inclusion) of the Preferred Reporting Items for Systematic Reviews and Meta-Analysis (PRISMA) (Moher et al. 2009) procedure was adopted in conducting this study. PRISMA consists of a four phase flow diagram to guide evidence-based systematic reviews and metaanalysis. The first step (identification) involves searching for relevant materials/documents to be included in the review. In this step, the emphasis was placed on documents dealing with gender, climate change, and COVID-19. The SCOPUS database, google scholar, and google search engine were used in identifying relevant materials. In SCOPUS, publications dealing with gender and climate change or COVID-19 were identified using two different search strings. The first search string focused on gender and climate change and is specified as: TITLE-ABS-KEY ("climate change" AND "gender" OR "gender vulnerability" AND "climate change") AND [LIMITTO (DOCTYPE, "ar") OR LIMIT-TO (DOCTYPE, "ch") OR LIMIT-TO (DOCTYPE, "re") OR LIMIT-TO (DOCTYPE, "bk")] AND [LIMIT-TO (LANGUAGE, "English")].

The search above was limited to articles, reviews, book chapters, and books authored in English only, and it churned out 1549 documents. The second search string focused on gender and COVID-19 and is specified as: TITLE-ABS-KEY ("gender" AND "COVID-19" OR "gender" AND "coronavirus" OR "gender" 
AND "sars-cov-2") AND [LIMIT-TO (DOCTYPE, "ar") OR LIMIT-TO (DOCTYPE, "re")] AND [LIMIT-TO (LANGUAGE, "English")]. The second string was limited to articles and reviews (no books and book chapters were found, though) authored in English only, and it produced 257 documents. These searches were conducted on November 2, 2020. A total of 32 documents were also identified through google scholar and the main google search engine using the search terms "gender equality + climate change" and "gender equality and COVID-19 or coronavirus". After checking for duplicates from the different sources, 17 documents were removed, hence a total of 1821 documents were screened for their eligibility. The few duplicates found is as a result of the different search strings used in the SCOPUS database which focused separately on COVID-Gender and Climate-Gender. Also, in the google scholar and google search engine, documents were screened within the search results and purposively selected and added to the total records screened.

In the second stage, the document titles and abstracts were screened, and relevant publications were selected for final assessment to determine their elibility for inclusion. This process resulted in the elimination 1597 documents, hence 224 documents were assessed for inclusion in the final stage. The documents were split among three researchers who conducted independent full-text assessments of the articles after which a cross-validation of each researchers selection was done. The final assessment included reading the full-text of the articles to determin their suitability for the topic under discussion. Emphasis was placed on documents that specifically focused on gender and climate change, gender and COVID-19 in terms of vulnerability and socioeconomic impacts, and interventions. This assessment resulted in the selection of 62 documents for inclusion. The entire process is summarized in the PRISMA flow chart below (See Fig. 1).

\section{Results and discussion}

The results and discussions in this section are based on the full-text analysis of the 62 documents selected. The majority of documents selected were journal articles (30) and reports (19). Figure 2 shows a classification of the document types and the years of publication. The reports were mainly from major international organizations such as the United Nations Entity for Gender Equality and the Empowerment of Women (UN Women), Organisation for Economic Co-operation and Development (OECD), International Labor Organization (ILO), United Nations Development Programme (UNDP), Agricultural Cooperative Development International (ACDI/VOCA), and CARE International, amongst others. The 30 journal articles selected comprised 25 original research articles and 5 review articles. A majority of the selected documents were published within the past five years with a cummulative total of 52 documents published from 2015 to 2020 . Hence, the most recent literature on the subject were included in our analysis. 


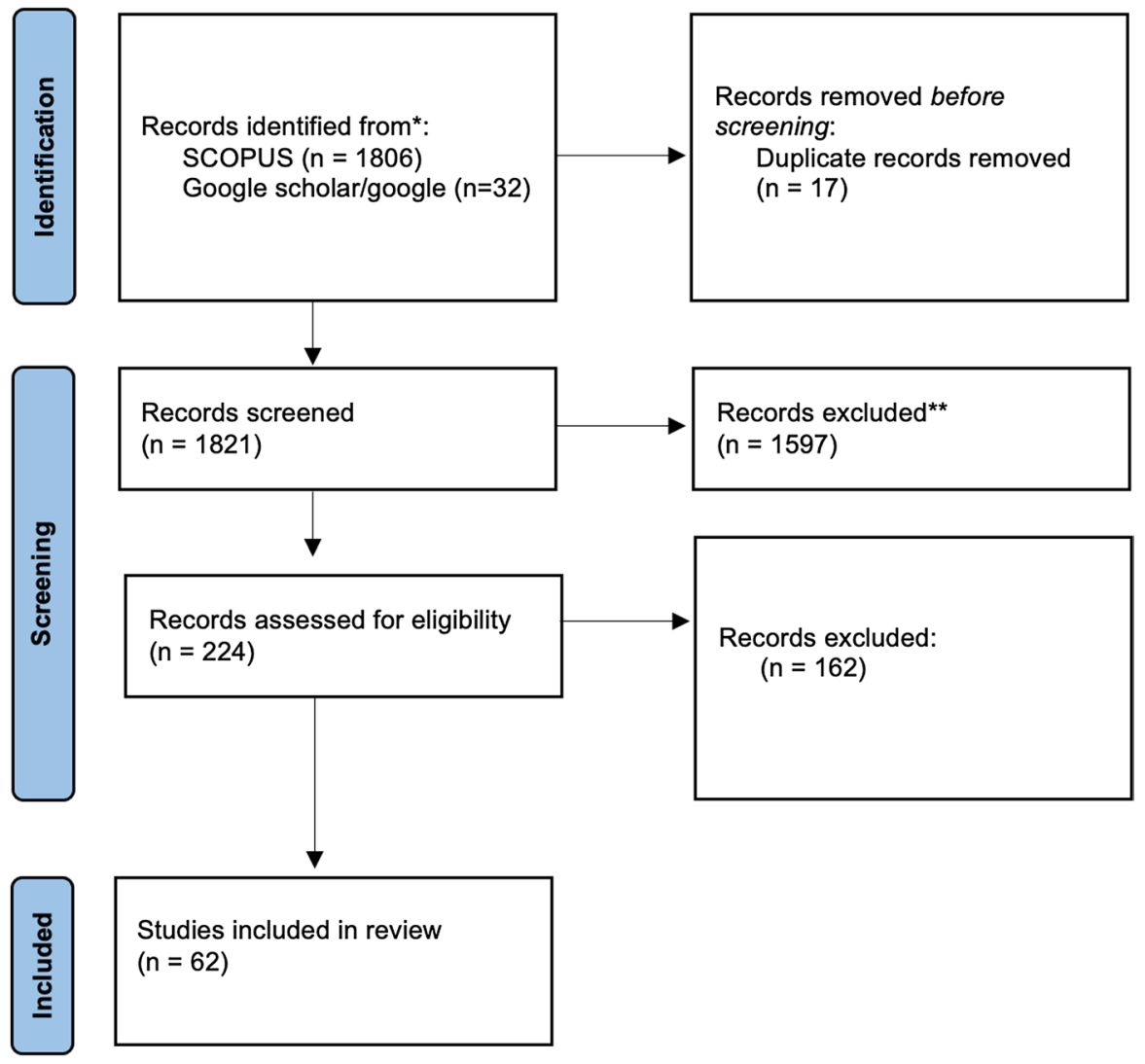

Fig. 1 Process of document identification and selection (PRISMA flow chart). Source: Adapted from Page et al. (2021)
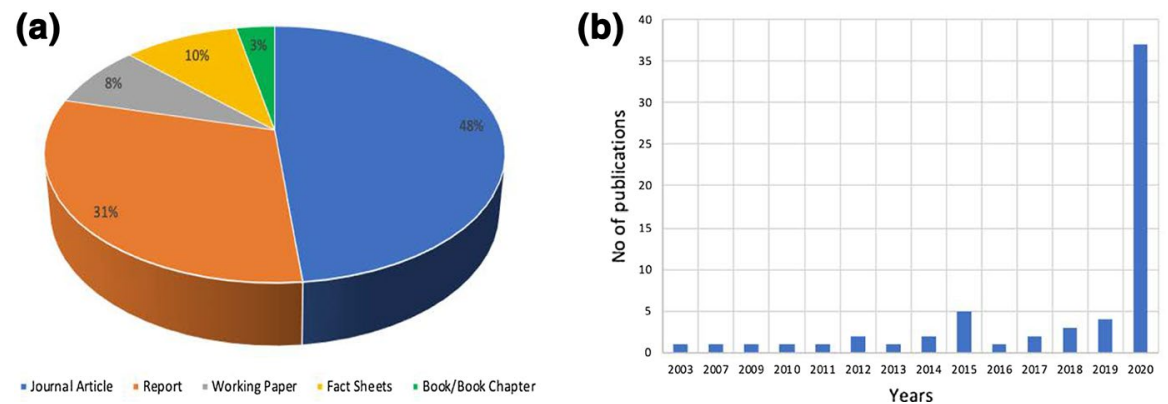

Fig. 2 Types of documents included in the review (a), and $\mathbf{b}$ publication years of documents 


\section{Nexus between the gendered socioeconomic impacts of COVID-19 and climate change}

The gender-related nexus between climate change and COVID-19 can be identified at two main levels - the vulnerability context and the socio-economic impacts. We conceptualize these nexus in Fig. 3, and emphasize that current responses to the gendered impacts of COVID-19 could help to address already exising gender

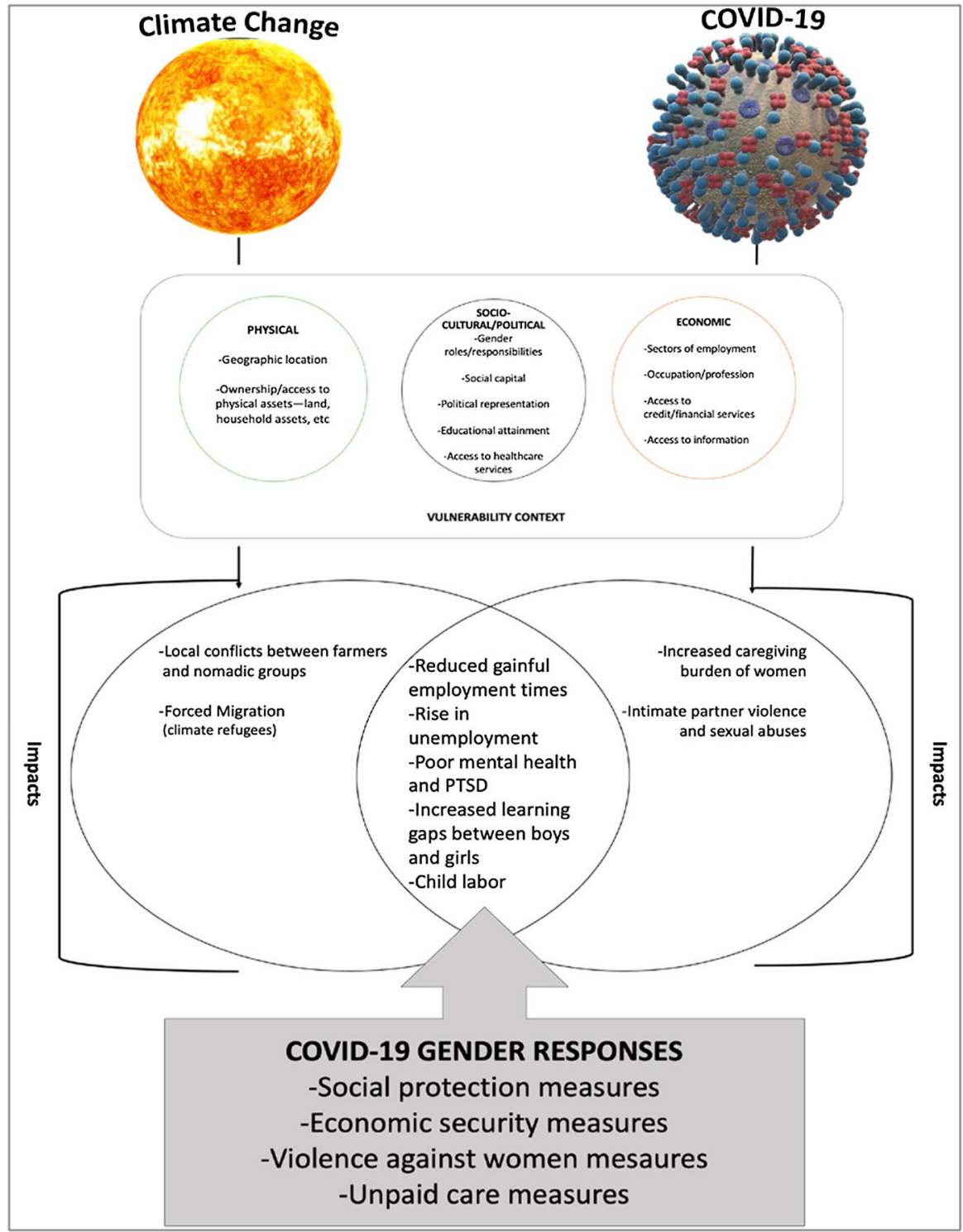

Fig. 3 Nexus between the gendered socio-economic impacts of COVID-19 and climate change 
impacts posed by climate change. While most the impacts are common to both, some impacts are exclusive to climate change only and COVID-19 only. Impacts like increased caregiving and intimate partner violence are more associated with COVID-19 than climate change due to COVID-19 infections and lockdowns which have confined people to their homes. On the other hand, forced migration and local conflicts (which disproportionately affect females), especially over local resources such as water and pasture, are more associated with climate change, particularly in the developing countries (Messer 2010). Two main nexuses have been deduced and discussed below.

\section{Nexus 1: the vulnerability context}

The Intergovernmental Panel on Climate Change (IPCC) defines a system's vulnerability to climate change based on exposure to climate hazards, systems sensitivity, and ability to adapt to these hazards (IPCC 2007). Hence, it is not the male or female gender itself that signifies vulnerability, but rather the specific context within which these genders are found (Wisner et al. 2003). For example, the UN Women (2020), noted that people's exposure to COVID-19 is influenced by gender, place of residence, and income. Abbasi et al. (2019) contend that vulnerabilities are produced by inequalities in the distribution and access to resources and opportunities. Several factors spanning economic, social, political, and cultural dimensions are, thus, very important determinants of peoples' vulnerability to climate-induced disasters and pandemics such as COVID-19. These factors have been clustered and discussed in three themes below-economic, socio-political, and physical.

Economic factors The economic setting holds significant implications for how both men and women are impacted by climate change and COVID-19, especially in the world's developing regions. Concerning climate change, many people's livelihoods are dependent on agricultural or natural resources (especially women). This dependence makes them directly susceptible to climate change impacts such as crop failures. However, women in particular have less access to agricultural credit, limited access to agricultural land and very few of them have bank accounts (African Development Bank 2018). According to the African Development Bank (2018), less than $1 \%$ of total credit to agriculture goes to women, while they benefit from only $10 \%$ of credit to small farmers. Limited financial services affect people's ability to access knowledge and information on climate risks and adaptation measures, and their ability to make investments that can help them to adapt or recover from climate-related disasters (Leichenko and Silva 2014) and pandemics such as COVID-19 (UN Women and UNEP 2020).

Also, more women than men are involved in the informal economy, which is prone to job insecurity. In sub-Saharan Africa, over $74 \%$ of women in non-agricultural jobs are in informal employment (UN Women 2015). This situation has been a major vulnerability factor for women during the pandemic. Lockdowns, stay at home measures, and market closures imposed due to the COVID-19 meant that most of these women employed in the informal sector were temporarily out of employment as many of them could not engage in their usual income 
generating activities (Alon et al. 2020; Asante and Mills 2020). In Europe, over 2.5 million workers are domestic workers who are mostly women in the informal economy, characterized by lower wages and poor conditions; hence, putting them in an economically vulnerable position (Baird and Hill 2020; European Union Agency for Fundamental Rights 2020). Unlike the 2008 recession, which affected more men than women in terms of job losses, the COVID-19 pandemic has negatively affected the service sectors such as the health, restaurants, and hospitality industries, which have high women employment (Alon et al. 2020). Low-paid jobs and activities such as laundry, cleaning, and food services in health facilities are mostly done by women making them very vulnerable to contracting diseases when there is an outbreak (Baird and Hill 2020).

Socio-cultural and political factors Gender roles and responsibilities, political representation/participation in decision making, social capital, and access to social services such as health are major factors that determine people's vulnerability to both climate change and COVID-19 impacts. Climate change has increased the household burden of women and girls', especially in developing countries, a situation that has been identified to worsen the economic vulnerability of women and girls since their gainful employment hours are reduced (Flat $\varnothing$ et al. 2017; Nabalamba et al. 2011). The majority of care work is also done by women as they are normally expected to care for children, take care of the elderly, and the sick. The closure of schools and daycare centers as a result of the COVID-19 pandemic, for instance, has increased the caregiving burden of women (Alon et al. 2020; McLaren et al. 2020). Also, existing inequalities in the ownership and control of household assets undermine women's ability to achieve economic independence and wellbeing (Flatø et al. 2017). Unfortunately, women's representation in the political sphere where decisions are made regarding these issues is limited (IUCN 2015; UNDP 2015).

The UNDP (2015), for instance, notes that globally less than $22 \%$ of seats in single/lower houses of national parliaments are occupied by women (UNDP 2015), while only $35 \%$ of environmental sector ministries have a gender focal point (IUCN 2015). Also, globally, $70 \%$ of the health and social sector workforce are women, and only $30 \%$ of them are in the management position to make decisions, thereby putting them at a greater risk to COVID-19 pandemic (OECD 2020; Oppenheim 2020). An individual's social capital is also an important determinant of their vulnerability during disasters or disease outbreaks (Goodrich et al. 2019; Gupta 2020). Gupta (2020) contends that social distancing and selfisolation measures in response to COVID-19 put victims of abusive partners in more danger as they will be far from family and friends.

Physical factors Physical factors such as geographic location and ownership of physical assets including land and household assets also play a significant role in the gender vulnerability to both climate change and COVID-19. Apropos climate change, people located in certain locations such as coastal and mountainous regions are more vulnerable to climate change impacts (Field et al. 2012; McDowell et al. 
2013). The vulnerability context also differs for rural and urban areas, with rural areas, in particular, being at a disadvantage. Due to inadequate infrastructure and access to facilities and services, rural dwellers may find it more difficult to adapt to climate change impacts. With regard to COVID-19, urban dwellers tend to be more vulnerable in terms of infections as the virus spreads quickly in the urban environment due to higher population densities and use of public spaces/services such as transport, restaurants/bars, and beaches, amongst others. Rural areas are, however, disadvantaged when it comes to access to health services, which is critical for testing and treatment of the virus. Socio-economically, urban areas may be hard hit by the pandemic since most lockdowns were mainly enforced in cities. These lockdowns, with their associated market closures alongside many other businesses affected more urban dwellers since the majority of these services are located in such areas. The different vulnerability factors discussed above imply that how the socio-economic impacts of climate change and COVID-19 are experienced along gender lines will also differ depending on the vulnerability context. The nexus between these impacts are is discussed below.

\section{Nexus 2: the socio-economic impacts}

The nexus between these impacts are also clustered and discussed in two themeseconomic and pyschosocial. The economic impacts focus on employmenent, income and poverty issues while psychosocial issues include anxiety and Post Traumatic Stress Disorder (PTSD), gender-based violence, learning gaps and child labor.

Economic impacts Climate change impacts such as droughts and other extreme weather events significantly disrupt livelihoods, while longer periods spent by women and women in securing fuelwood and water for their households also affects their gainful employment times (Kwauk et al 2019). Similarly, COVID-19 lockdowns, market closures, and associated measures have also resulted in unemployment and have increased care work for women, which has affected their gainful employment times. As of April 2020, the World Bank estimated that COVID-19 has pushed between 40 and 60 million people back into poverty, with most of them in developing countries (Mahler et al. 2020). With the majority of people already living in poverty being women (UN Women 2018), the pandemic is taking a heavier toll on them than their male counterparts. Climate change impacts are also known to exacerbate the cycle of poverty, especially in the developing world, where many livelihoods are natural-resource dependent (WEDO 2016). With crop failures and water scarcity, household income is affected, and in turn limits the ability to feed the family and pay for social services such as education and healthcare,

An area that was key in stopping the spread of the COVID-19 virus was the market places, which were closed in order to decongest populated markets and enforce social distancing among traders (Asante and Mills 2020). These measures have affected women since they play key roles as processors, traders, and entrepreneurs in markets, thus, limiting their working opportunities. Women globally earn much lesser income than their men counterparts. Therefore, income losses because of the global coronavirus pandemic would increase the inequalities between them (World 
Trade Organization 2020). Also, many companies' COVID19-related layoffs have focused on female employees (Kurter 2020; Robbins 2020). All these impacts have potentially widened the economic inequality gap between men and women.

Psychosocial impacts COVID-19 and climate change have common social and psychological impacts. Regarding climate change, Padhy et al. (2015) noted that increasing temperatures and prolonged droughts can increase rates of aggression and farmer suicides, while frequent climate-related disasters such as hurricanes can lead to Post Traumatic Stress Disorder (PTSD), adjustment disorder, and depression. Similarly, the COVID-19 pandemic has led to increased anxiety, stress, and PTSD symptoms (Liu et al. 2020; Özdin and Bayrak Özdin 2020). People with track records of genderbased violence or intimate partner violence experienced mental health challenges due to the negative consequences of isolation and stay home measures across countries (Raj et al. 2020). The imposition of social distancing and self-isolation put victims of abusive partners in more danger as they are far from family and friends (Gupta 2020). Consequently, there has been a sharp increase in emergency calls to helplines and increased online searches for support by domestic violence victims during the pandemic period. Domestic violence-related deaths in the UK alone increased by twofold within two weeks of the lockdown period (Chen and Bougie 2020). Women tend to be more domestic violence victims than men are during pandemics and epidemics (Scotland 2020). Unfortunately, COVID-19 has also disrupted reproductive, mental health, and psychosocial support services due to the diversion of resources from these services to tackle the pandemic (CARE International 2020; Raj et al. 2020).

Climate change and COVID-19 also widen the education access and equity gap between males and females. Kwauk et al. (2019) noted that due to their gender roles within the household, girls' education is impacted more by climate change than their male counterparts, with the millions of hours spent collecting water and fuelwood significantly affecting girls' enrollment and retention in school (Kwauk et al. 2019). According to UN Women (2018), about 15 million girls of primary-schoolage will never get the chance to learn to read or write as compared to 10 million boys. The United Nations Development Programme (UNDP 2015) estimates that about $80 \%$ of people displaced by climate change are women. Hence, in the event of such displacements, most school-going girls are more likely to be affected than boys. Similarly, Scotland (2020) noted that the COVID-19 pandemic and school closures increase the existing learning gaps between boys and girls, and could potentially lead to early marriages. School closures also meant that children could not report domestic violence and sexual abuses to teachers they mostly confide in (Scotland 2020; UN Women 2020).

Another shared impact of COVID-19 and claimate change is child labour. Adverse climate change impacts on agriculture often force households to seek alternative livelihoods, a situation which forces children to work under dangerous conditions (ReliefWeb 2017), while livelihood disruptions caused by COVID-19 and school closures also force children to provide temporary support for their families often through income-generating activities which subjects them to child labor (ILO and UNICEF 2020). The foregoing shows that most of the gendered socioeconomic impacts of COVID-19 and climate change are connected. While the pandemic is 
taking a heavy toll on societies, it has also brought opportunities to address these problems. The pandemic has spurred massive resource mobilizations towards addressing its impacts, and to build back better. Several measures in response to the gendered impacts are being enacted and implemented across the world. With the interconnectedness discussed above, these measures can be leveraged to address the gender impacts of climate change as well.

\section{Gender-based responses to the COVID-19 pandemic}

According to the UNDP and UN Women (UNDP and UN Women 2020e), 164 countries and territories out of 206 countries and territories that they analyzed have adopted some gender-sensitive measures in response to the COVID-19 pandemic. These measures are broadly categorized into those that address violence against women, women's economic security, and unpaid care and are presented in Fig. 4. Overall, the majority of these measures target violence against women; economic security measures constitute the least among the three categories. In-depth discussion of these interventions are given below.

\section{Social protection measures}

Social protection measures could be classified as gender-sensitive if they address women's unpaid care (UNDP-UN Women 2020). Unpaid care, as defined by Ryan and Ayadi (2020) refers to all non-market, unpaid activities carried out in

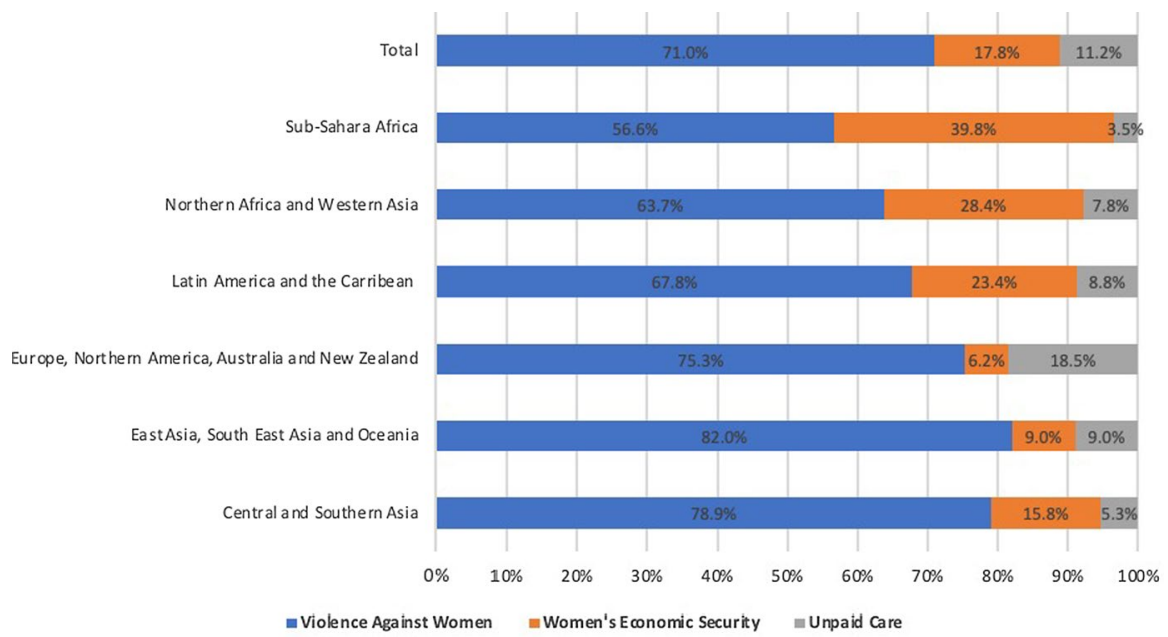

Fig. 4 Gendered responses to COVID-19 in various regions of the world. Total $(n=992)$, sub-Sahara Africa $(n=113)$, Northern Africa and Western Asia $(n=102)$, Latin America and the Caribbean $(n=261)$, Europe, Northern America, Australia and New Zealand $(n=340)$, East Asia, South East Asia and Oceania $(n=100)$, Central and Southern Asia $(n=76)$. Source: Authors' construct based on data from UNDP and UN Women (2020e) 
households - and includes both direct care of persons, such as children or the elderly and indirect care such as cleaning, cooking, or fetching water. Globally, only $8 \%$ of gender responses to COVID-19 focus on unpaid care (UNDP and UN Women 2020e). These measures were in the form of social insurance, care services, and social assistance. The most common measures were provisions for family leave, which enabled parents to spend some of their paid work time in caring for children and sick relatives, while social assistance measures included compensations to parents for the closure of schools and daycare centers (UNDP and UN Women 2020e). Despite numerous social protection measures in the developing world, only a few of them address gender concerns. For instance, in sub-Sahara Africa (SSA), measures that focus on unpaid care and women's economic security make up only a fraction of the total social protection response, on the one hand, and fiscal and economic interventions, on the other. About 45 territories and countries in SSA have endorsed 189 social protection and labor market measures as COVID-19 responses. However, only 30 (15.9\%) of these measures are gender-sensitive in that they strengthen women's economic security or deal with unpaid care (UNDP and UN Women 2020d). Similarly, out of 70 social protection measures adopted in the Central and Southern Asia region, only $13(18.6 \%)$ of them are gender-sensitive, while only $75(22 \%)$ out of 339 social protection measures in the Latin America and Caribbean region were gender-sensitive (UNDP and UN Women 2020a, b).

\section{Labour market measures}

By definition, labor market measures are gender-sensitive if they target women's economic security (UNDP-UN Women 2020). Alon et al. (2020) reported that the United States government, as a labor market measure, permitted flexible work arrangements for public organizations, allowing working mothers to work remotely while attending to their children's increased care needs. Following the report of the UNDP and UN Women (2020e), out of the 1813 fiscal, economic, social protection, and labor market measures to tackle COVID-19 impacts on women in more than 200 countries and territories, only 177 measures across 85 countries and territories deal with women's economic security or lack of it-resulting to a meagre 10 percent of the total fiscal, economic, social protection and jobs responses. Labor market measures account for 19 percent of measures that deal with women's economic security (33 measures across 20 countries), covering training programs that target women, wage subsidies, and support for women entrepreneurs and women employed in the informal sector (UNDP and UN Women 2020e).

As an example, in the wake of the COVID-19 pandemic, three African countries launched programs aimed at supporting women entrepreneurs, informal traders, and cooperatives with cash transfers, credits subsidy, grants and/or digital platforms to market local products. The global labor market measures to address the gendered COVID-19 impacts could be generally inadequate as only 20 countries of the world have labor market measures that prioritize, or at least, target the women sector (UNDP and UN Women 2020e). 


\section{Fiscal and economic measures}

In the context of this study, fiscal and economic measures are said to be gender-sensitive if they support the female-dominated sectors of the economy, on the premise that this will protect women's employment, thus enhancing their economic security. According to the UNDP-UN Women (2020), 31 countries and territories in SubSaharan Africa have employed 98 fiscal and economic measures to assist the businesses. However, only 19 of these measures have sought to strengthen women's economic security by channeling resources to feminized sectors. It is pertinent to highlight at this point that given the lower number of measures to address unpaid care, no country in sub-Saharan Africa registers a holistic response with measures that span the three dimensions (unpaid care, violence, and economic security). Worrisomely, 16 out of 45 countries and territories analyzed in the region have no gender-sensitive measures in all of their COVID-19 responses.

Globally, the key social protection programs that governments have adopted to also fortify women's economic security with regard to COVID-19 are: cash transfers (51 of these measures are found in 41 countries) and food assistance or other forms of in-kind support (21 of these measures are found in 20 countries) that prioritize women as the major recipients (UNDP and UN Women 2020e). For example, as a fiscal and economic measure for combatting COVID-19 effects on women, the government of Rwanda, from April to September 2020, targeted female-headed Rwandan households and capitalized on its decentralized governance structure to distribute food and other important items to about 20,000 families. Target groups included casual laborers who lost their livelihoods due to the COVID-19 lockdown measures. In general, only 35 countries of the world included fiscal measures that channel resources to female-dominated sectors in their overall COVID-19 responses (UNDP and UN Women 2020e).

\section{Violence against women measures}

Several countries have implemented policies of paid sick leave for caregivers (mostly women), childcare support and child feeding programmes. Some countries have created child helplines to receive reports of violence, while others have integrated child protection into COVID-19 responses helplines (Bhatia et al. 2020). Alteration of stay-at-home orders for women experiencing violence, secretly reporting violence through smartphone apps and helplines, enabling reporting of violence through supermarkets or pharmacies, and providing emergency shelter for women and their children in case of violence are some of the measures taken in response to violence against women. About 57 percent of all gender-sensitive measures in SubSaharan Africa (i.e., 64 measures across 17 countries) deal with preventing and/or responding to violence against women and girls (VAWG).

The UNDP and UN Women (2020c) reports that Eastern and Southern African countries account for an approximated two-thirds of VAWG measures (46 measures across 11 countries). In comparison, Central and Western African countries have around one-third of measures (18 measures across six countries) to address violence against women. The goal of more than 50 percent of all VAWG measures in the 
Sub-Saharan African region (35 in 13 countries) is to strengthen services for women who survived violence through continual provision of psychosocial support (seven measures in six countries), provision of helplines and other reporting mechanisms (11 measures in 10 countries), and prompt police and judicial responses (seven measures in six countries).

\section{Leveraging covid-19 responses to address gender impacts of climate change}

From the discussions above it is apparent that there is a nexus between the gendered impacts of COVID-19 and climate change. These commonalities imply, as we elaborate here, that COVID-19 responses can be leveraged to simultaneously address the gendered impacts of climate change. Some of the labour market measures adopted by many African governments include training programmes that target woment in the informal sector who lost their jobs due to COVID-19, wage subsidies, and support for women entrepreneurs. These measures have a positive climate change dimension. For instance, in addition to supporting these women to set up entrepreneurship ventures on their own, the training programmes for them could focus on income-generating green skills that can enhance employment in the aftermath of COVID-19 while engendering a shift towards decarbonization, and ultimately climate change mitigation. The measures can be tailored to encourage women in agriculture to pursue sustainable agriculture or other rural entrepreneurial activities that could enhance ecosystem regeneration and clean energy installations (Agrawalai et al. 2020) Also, van Barneveld et al. (2020) opined that government support for renewable energy startups owned and operated by women would not just enhance their economic security but may also smoothen the transition to clean energy, which in turn, could reduce emissions and thus, combat climate change. This assertion is also supported by Borland and Charlton (2020)

The climate dimension of the fiscal and economic measures adopted to address COVID-19 gendered impacts is also significant. Many African governments (Rwanda as a point of reference), distributed food and other essential items to families, especially those headed by women. By providing the basic food necessities to these female-headed households, the women are discouraged from certain environtally unfriendly practices such as cutting of trees to sell as fuelwood, animal poaching and consumption of wild fruits which could affect the environment negatively and further expose the country to climate change risks (Hepburn et al. 2020). Also, the aim of more than 50 percent of all VAWG measures in the Sub-Saharan African region is to strengthen services for women who survived violence through different forms of assistance including economic support. While the VAWG measures may not have a direct role in the climate change context, some of the measures aimed at strengthening women who survived COVID-19-induced violence may also bolster their adaptation to climate change impacts. Programmes that seek to re-establish the economic strength of the violated women are particularly important in this regard. They could come in the form of green entrepreneurship support or clean energy skills acquisition programmes. 


\section{Conclusion and recommendations}

The COVID-19 virus, also known as sars-cov-2, continues to impact severely in all facets of society. The pandemic has brought in its wake severe disruptions, which have placed an enormous task on governments to both respond by containing the spread of the virus, treat infected people, and find ways to recover and get economies back to normal. The pandemic essentially added to the climate change problem which the world has been battling. Both problems have caused unprecedented impacts, sending shocks across various regions of the world and impacting different groups of people in different ways. Previous studies have shown that in such unprecedented circumstances due to disease outbreaks or disasters, gender is critical since gender roles and responsibilities influence how men and women are affected by these disruptions. In this paper, we establish a nexus between the gendered socioeconomic impacts of COVID-19 and climate change and argue that resources being mobilized to address the impacts of the COVID-19 could be leveraged to address the impacts of climate change with regard to gender. Both climate change and COVID-19 were found to reduce gainful employment times, cause unemployment, cause mental health problems, including PTSD, increase learning gaps between boys and girls, and cause child labor. In all these impacts, the female gender in particular tends to be disadvantaged and bear the brunt of these impacts due to their gender roles and responsibilities.

Countries around the world have taken cognizance of the gendered impacts of the pandemic and have initiated measures to address these impacts. These measures were broadly categorized into measures that deal with violence against women, women's economic security, and unpaid care. However, available data shows that very few countries have measures that address all three issues. Even though a total of 992 gender-sensitive measures were found in 164 countries, only 25 countries have measures that target all the three issues identified (UNDP and UN Women 2020e). Nonetheless, social protection, labor market, economic, and violence against women measures adopted by countries in response to the pandemic provide a good opportunity to address the gender impacts of climate change as well. However, the fact that the current measures adopted in response to COVID-19 do not highlight these linkages implies that the commonalities between the gendered impacts of the pandemic and climate change have not been recognized. This study, thus, draws attention to a very important issue. We argue that COVID-19 and climate change are not so different in terms of their gendered-socio-economic impacts. Hence, efforts to address these impacts should be streamlined to ensure resource-efficiency and also ensure that the measures taken in response to the pandemic do not end when the pandemic is over since the same measures are crucial for addressing the gendered impacts of climate change, which is a long-term phenomenon.

Observably, most of the gender-sensitive measures taken by countries in response to the pandemic have a women-focus. This is understandable since the female gender in particular has been identified to bear most of the negative impacts. However, even though the female gender is generally found to be more 
vulnerable, contextual factors tend to make some more vulnerable to climaterelated disasters and disease outbreaks than others. It is currently unclear how these contextual factors or differences have been factored into the COVID-19 gender-sensitive responses. Also, while the male gender is usually considered less vulnerable, the same contextual factors such as location, educational levels, disability status, economic and social capital amongst may make the male gender in some contexts more vulnerable to climate-related disasters and disease outbreaks such as the COVID-19. Thus, future research could examine these dynamics to better understand and formulate context-specific policy responses for a more inclusive and equitable post-pandemic recovery.

Author contributions MA: conceptualization, methodology, visualization, writing-original draft preparation, writing — reviewing and editing. MM: writing—original draft preparation, writing — reviewing and editing. $\mathrm{CN}$ : writing —original draft preparation, writing—reviewing and editing.

Funding No funding was received for conducting this study.

Data availability All data analysed are contained in the article.

\section{Declarations}

Conflict of interest The authors have no conflicts of interest to declare that are relevant to the content of this article.

\section{References}

Abbasi SS, Anwar MZ, Habib N, Khan Q, Waqar K (2019) Identifying gender vulnerabilities in context of climate change in Indus basin. Environ Dev 31:34-42. https://doi.org/10.1016/j.envdev.2018.12. 005

African Development Bank. (2018). From policy to action: integrating gender into national climate actions in Africa. https://www.afdb.org/en/news-and-events/cop24-from-policy-to-action-integrating-gender-into-national-climate-actions-in-africa-18834. Accessed 3 Nov 2020

Agrawalai S, Dussauxi D, Montii N (2020). What policies for greening the crisis response and economic recovery?: Lessons learned from past green stimulus measures and implications for the COVID-19 crisis (No. 164; OECD Environment Working Papers). https://doi.org/10.1787/c50f186f-en

Alon TM, Doepke M, Olmstead-Rumsey J, Tertilt M (2020). The impact of COVID-19 on gender equality (No. 26947; NBER working paper series). http://www.nber.org/papers/w26947. Accessed 16 Nov 2020

Arora S, Bhaukhandi KD, Mishra PK (2020) Coronavirus lockdown helped the environment to bounce back. Sci Total Environ 742:140573. https://doi.org/10.1016/j.scitotenv.2020.140573 (Elsevier B.V)

Asante LA, Mills RO (2020) Exploring the socio-economic impact of COVID-19 pandemic in marketplaces in Urban Ghana. Afr Spectr. https://doi.org/10.1177/0002039720943612

Baird M, Hill E (2020). COVID-19 and women's economic participation. https://www.sydney.edu.au/ content/dam/corporate/documents/business-school/research/women-work-leadership/covid-19report.pdf. Accessed 2 Nov 2020

Bhadwal S, Sharma G, Gorti G, Sen SM (2019) Livelihoods, gender and climate change in the Eastern himalayas. Environ Dev 31:68-77. https://doi.org/10.1016/j.envdev.2019.04.008

Bhatia A, Fabbri C, Cerna-Turoff I, Tanton C, Knight L, Turner E, Lokot M, Lees S, Cislaghi B, Peterman A, Guedes A, Devries K (2020) COVID-19 response measures and violence against children. Bull World Health Organ 98(9):583-583A. https://doi.org/10.2471/BLT.20.263467 
Blundell R, Costa Dias M, Joyce R, Xu X (2020) COVID-19 and Inequalities*. Fisc Stud 41(2):291-319. https://doi.org/10.1111/1475-5890.12232

Borland J, Charlton A (2020) The Australian labour market and the early impact of COVID-19: an assessment. Aust Econ Rev 53(3):297-324. https://doi.org/10.1111/1467-8462.12386

Bradshaw S (2015) Engendering development and disasters. Disasters 39(s1):s54-s75. https://doi.org/10. 1111/disa. 12111

CARE International (2020) Gender implications of covid-19 outbreaks in development and humanitarian settings. Gend Dev. https://doi.org/10.1080/13552074.2019.1615288

Chauhan P (2020) Gendering COVID-19: impact of the pandemic on women's burden of unpaid work in India. Gend Issues. https://doi.org/10.1007/s12147-020-09269-w

Chen I, Bougie O (2020) Women's issues in pandemic times: how COVID-19 has exacerbated gender inequities for women in Canada and around the world. J Obstet Gynaecol Can. https://doi.org/10. 1016/j.jogc.2020.06.010

Collins C, Landivar LC, Ruppanner L, Scarborough WJ (2020) COVID-19 and the gender gap in work hours. Gend Work Organ. https://doi.org/10.1111/gwao.12506

Eastin J (2018) Climate change and gender equality in developing states. World Dev 107(2018):289-305. https://doi.org/10.1016/j.worlddev.2018.02.021

European Union Agency for Fundamental Rights F. (2020). Out of sight: migrant women exploited in domestic work. Publication Office of the EU. https://doi.org/10.2811/064348

Field C, Barros V, Stocker T, and Dahe Q (2012). Managing the risks of extreme events and disasters to advance climate change adaptation: special report of the intergovernmental panel on climate change. Intergovernmental Panel on Climate Change. https://books.google.com/books?hl=en\&lr=\&id= nQg3SJtkOGwC\&oi=fnd\&pg=PR4\&ots=14CfrunBUU\&sig=7jvTXGZpSINJGb12SYHv-NycV8 o (accessed November 1, 2020)

Flatø M, Muttarak R, Pelser A (2017) Women, weather, and woes: the triangular dynamics of femaleheaded households, economic vulnerability, and climate variability in South Africa. World Dev 90:41-62. https://doi.org/10.1016/j.worlddev.2016.08.015

Goli I, Najafabadi MO, Lashgarara F (2020) Where are we standing and where should we be going? gender and climate change adaptation behavior. J Agric Environ Ethics 33:187-218. https://doi.org/10. 1007/s10806-020-09822-3

Goodrich CG, Udas PB, Larrington-Spencer H (2019) Conceptualizing gendered vulnerability to climate change in the Hindu Kush Himalaya: Contextual conditions and drivers of change. Environ Dev 31:9-18. https://doi.org/10.1016/j.envdev.2018.11.003

Gupta, J. (2020, March 19). What does coronavirus mean for violence against women?-women's media center. WMC news \& features. https://womensmediacenter.com/news-features/what-does-coronavirus-mean-for-violence-against-women. Accessed 1 Nov 2020

Hepburn C, O'Callaghan B, Stern N, Stiglitz J, Zenghelis D (2020) Will COVID-19 fiscal recovery packages accelerate or retard progress on climate change? Oxford Rev Econ Policy 36(Supplement_1):S359-S381. https://doi.org/10.1093/oxrep/graa015

ILO and UNICEF. (2020). COVID-19 and child labour: a time of crisis, a time to act. https://www.unicef. org/sites/default/files/2020-06/COVID-19-and-Child-labour-2020.pdf. Accessed 5 Nov 2020

IPCC. (2007). Climate Change 2007: Impacts, adaptation and vulnerability. contribution of working group II to the fourth assessment report of the intergovernmental panel on climate change. Glossary In: Parry M, Canziani O, Palutikof J, van der Linden P, Hanson C (eds.). Cambridge University Press

IUCN. (2015). Gender focal points and policies in national environmental ministries (EGI Brief). http:// www.wocan.org/sites/default/files/EGI_focal_point_brief_sept15_0.pdf. Accessed 5 Nov 2020

Kurter HL (2020). 3 Ways to layoff employees with dignity during a crisis. https://www.forbes.com/sites/ heidilynnekurter/2020/03/31/3-ways-to-layoff-employees-with-dignity-during-a-crisis/?sh=488f6 0f42f7f. Accessed 2 Nov 2020

Kwauk C, Cooke J, Hara E, Pegram J. (2019). Girls' education in climate strategies (No. 133; global economy \& development). https://www.brookings.edu/research/girls-education-in-climate-strat egies/. Accessed 8 Nov 2020

Le Quéré C, Jackson RB, Jones MW, Smith AJP, Abernethy S, Andrew RM, De-Gol AJ, Willis DR, Shan Y, Canadell JG, Friedlingstein P, Creutzig F, Peters GP (2020) Temporary reduction in daily global CO2 emissions during the COVID-19 forced confinement. Nat Clim Chang 10(7):647-653. https:// doi.org/10.1038/s41558-020-0797-X 
Leckie J (2016) Development, gender and security in a new millennium. In: Leckie J (ed) Development in an insecure and gendered world: the relevance of the millennium goals, 1st edn. Routledge, New York, pp 21-46. https://doi.org/10.4324/9781315576862-8

Leichenko R, Silva JA (2014) Climate change and poverty: vulnerability, impacts, and alleviation strategies. Wiley Interdiscip Rev 5(4):539-556. https://doi.org/10.1002/wcc.287

Liu N, Zhang F, Wei C, Jia Y, Shang Z, Sun L, Wu L, Sun Z, Zhou Y, Wang Y, Liu W (2020) Prevalence and predictors of PTSS during COVID-19 outbreak in China hardest-hit areas: gender differences matter. Psychiatry Res. https://doi.org/10.1016/j.psychres.2020.112921

Mahler DG, Lakner C, Aguilar AC, Wu H. (2020). The impact of COVID-19 (coronavirus) on global poverty: why Sub-Saharan Africa might be the region hardest hit. https://blogs.worldbank.org/opend ata/impact-covid-19-coronavirus-global-poverty-why-sub-saharan-africa-might-be-region-hardest. Accessed 2 Nov 2020

Markard J, Rosenbloom D (2020) A tale of two crises: COVID-19 and climate. Sustainability 16(1):5360. https://doi.org/10.1080/15487733.2020.1765679

McDowell G, Ford JD, Lehner B, Berrang-Ford L, Sherpa A (2013) Climate-related hydrological change and human vulnerability in remote mountain regions: a case study from Khumbu Nepal. Reg Environ Change 13(2):299-310. https://doi.org/10.1007/s10113-012-0333-2

McLaren HJ, Wong KR, Nguyen KN, Mahamadachchi KND (2020) Covid-19 and women's triple burden: vignettes from Sri Lanka, Malaysia Vietnam and Australia. Soc Sci 9(5):87. https://doi.org/10. 3390/SOCSCI9050087

Messer, E. (2010). Climate change and violent conflict: a critical literature review Ellen Messer 2 climate change and violent conflict. https://www.oxfamamerica.org/static/media/files/climate-change-andviolent-conflict.pdf. Accessed 2 Nov 2020

Moher D, Liberati A, Tetzlaff J, Altman DG (2009) Preferred reporting items for systematic reviews and meta-analyses: the PRISMA statement. Br Med J Publ Group 339(7716):332-336. https://doi.org/ 10.1136/bmj.b2535

Momsen, J. H. (2019). Gender and development (3rd edn). Routledge. https://books.google.com.gh/ books/about/Gender_and_Development.html?id=7ek0vgAACAAJ\&redir_esc=y. Accessed 11 Nov 2020

Muhammad S, Long X, Salman M (2020) COVID-19 pandemic and environmental pollution: a blessing in disguise? Sci Total Environ 728:138820. https://doi.org/10.1016/j.scitotenv.2020.138820

Nabalamba A, Mubila M, Alexander P. (2011). Climate change, gender and development in Africa (No. 1; chief economists complex). https://www.afdb.org/sites/default/files/documents/publications/clima te_change_gender_and_development_in_africa.pdf. Accessed 2 Nov 2020

OECD. (2020). COVID-19 in Africa: regional socio-economic implications and policy priorities. https:// d33qd0x2bmhjip.cloudfront.net/ea29e746-c955-49bf-b69a-fe10f70cb00d/downloads/insights/oecd. pdf. Accessed 2 Nov 2020

Oppenheim M (2020). Only one in eight countries safeguarding women against social impacts of coronavirus, UN study finds . The Independent. https://www.independent.co.uk/news/women-coronavirusviolence-lockdown-support-economic-care-work-impact-b597151.html. Accessed 2 Nov 2020

Özdin S, Bayrak Özdin Ş (2020) Levels and predictors of anxiety, depression and health anxiety during COVID-19 pandemic in Turkish society: the importance of gender. Int J Soc Psychiatry 66(5):504511. https://doi.org/10.1177/0020764020927051

Padhy SK, Sarkar S, Panigrahi M, Paul S (2015) Mental health effects of climate change. Indian J Occup Environ Med 19(1):3-7. https://doi.org/10.4103/0019-5278.156997 (Medknow Publications)

Page MJ, McKenzie JE, Bossuyt PM, Boutron I, Hoffmann TC, Mulrow CD, Shamseer L, Tetzlaff JM, Akl EA, Brennan SE, Chou R, Glanville J, Grimshaw JM, Hróbjartsson A, Lalu MM, Li T, Loder EW, Mayo-Wilson E, McDonald S, McGuinness LA, Stewart LA, Thomas J, Tricco AC, Welch VA, Whiting P, Moher D (2021) The PRISMA 2020 statement: an updated guideline for reporting systematic reviews. BMJ 372:n71. https://doi.org/10.1136/bmj.n71

Paital B (2020) Nurture to nature via COVID-19, a self-regenerating environmental strategy of environment in global context. Sci Total Environ 729:139088. https://doi.org/10.1016/j.scitotenv.2020. 139088

Raj A, Johns NE, Barker KM, Silverman JG (2020) Time from COVID-19 shutdown, gender-based violence exposure, and mental health outcomes among a state representative sample of California residents. EClinicalMedicine. https://doi.org/10.1016/j.eclinm.2020.100520 
ReliefWeb. (2017). Child labour report 2017: the neglected link, effects of climate change and environmental degradation on child labour. https://reliefweb.int/report/world/child-labour-report-2017neglected-link-effects-climate-change-and-environmental. Accessed 5 Nov 2020

Robbins R (2020) Healthcare layoffs during the COVID-19 pandemic. Southwest J Pulm Crit Care 20(4):135-136. https://doi.org/10.13175/swjpcc029-20

Rugani B, Caro D (2020) Impact of COVID-19 outbreak measures of lockdown on the Italian carbon footprint. Sci Total Environ 737:139806. https://doi.org/10.1016/j.scitotenv.2020.139806

Ryan NE, El Ayadi AM (2020) A call for a genderresponsive, intersectional approach to address COVID19. Global Public Health, 1-9. https://doi.org/10.1080/17441692.2020.1791214

Saadat S, Rawtani D, Hussain CM (2020) Environmental perspective of COVID-19. Sci Total Environ 728:138870. https://doi.org/10.1016/j.scitotenv.2020.138870 (Elsevier B.V.)

Sanaul M, Mondal H (2014) Women's vulnerabilities due to the impact of climate change: case from Satkhira Region of Bangladesh. Glob J Human-Soc Sci 14:46-52

Scotland, P. (2020). Covid-19 has led to a rise in domestic violence-tackling this hidden pandemic requires concerted action. The Independent. https://www.independent.co.uk/voices/coronaviruscovid-19-pandemic-domestic-violence-commonwealth-a9540091.html. Accessed 2 Nov 2020

Sovacool BK, Furszyfer Del Rio D, Griffiths S (2020) Contextualizing the Covid-19 pandemic for a carbon-constrained world: Insights for sustainability transitions, energy justice, and research methodology. Energy Res Soc Sci 68:101701. https://doi.org/10.1016/j.erss.2020.101701

Stemple L, Karegeya P, Gruskin S (2016) Human rights, gender, and infectious disease: from HIV/AIDS to ebola. Hum Rights Q 38(4):993-1021. https://doi.org/10.1353/hrq.2016.0054

UN Women, UNEP. (2020). Gender and climate change in the context of COVID-19. https://bit.ly/ 2L9BDy3 . Accessed 3 Nov 2020

UN Women. (2015). Women in informal economy I un women. https://www.unwomen.org/en/news/infocus/csw61/women-in-informal-economy. Accessed 3 Nov 2020

UN Women. (2018). Turning promises into action: Gender equality in the 2030 agenda for sustainable development. UN Women SDGs Monitoring Report. https://www.unwomen.org/en/digital-libra ry/publications/2018/2/gender-equality-in-the-2030-agenda-for-sustainable-development-2018. Accessed 2 Nov 2020

UN Women. (2020). Rapid gender impact assessments of COVID-19. A guide to integrate gender into socio-economic impact assessments of COVID-19 I UN women-Africa. https://africa.unwom en.org/en/digital-library/publications/2020/04/a-guide-to-integrate-gender-into-socio-economicimpact-assessments-of-covid-19. Accessed 2 Nov 2020

UNDP, UN Women. (2020a). COVID-19 global gender response tracker fact sheets: Central and Southern Asia. https://www.undp.org/content/undp/en/home/librarypage/womens-empowerment/COVID19-Global-Gender-Response-Tracker.html. Accessed 3 Nov 2020

UNDP, UN Women. (2020b). COVID-19 global gender response tracker fact sheets: latin America and Caribbean. https://www.undp.org/content/undp/en/home/librarypage/womens-empowerment/ COVID-19-Global-Gender-Response-Tracker.html. Accessed 3 Nov 2020

UNDP, UN Women. (2020c). COVID-19 Global gender response tracker fact sheets: Sub-Sahara Africa. https://www.undp.org/content/undp/en/home/librarypage/womens-empowerment/COVID19-Global-Gender-Response-Tracker.html. Accessed 3 Nov 2020

UNDP, UN Women. (2020d). COVID-19 global gender response tracker fact sheets:Sub-Sahara Africa. https://www.undp.org/content/undp/en/home/librarypage/womens-empowerment/COVID-19Global-Gender-Response-Tracker.html. Accessed 3 Nov 2020

UNDP, UN Women. (2020e). COVID-19 global gender response tracker fact sheets: Global. https://www. undp.org/content/undp/en/home/librarypage/womens-empowerment/COVID-19-Global-GenderResponse-Tracker.html. Accessed 3 Nov 2020

UNDP. (2015). Gender and climate change: overview of linkages between gender and climate change. https://reliefweb.int/sites/reliefweb.int/files/resources/UNDP\%20Linkages\%20Gender\% 20and\%20CC\%20Policy\%20Brief\%201-WEB.pdf. Accessed 2 Nov 2020

van Barneveld K, Quinlan M, Kriesler P, Junor A, Baum F, Chowdhury A, Junankar P, Clibborn S, Flanagan F, Wright CF, Friel S, Halevi J, Rainnie A (2020) The COVID-19 pandemic: lessons on building more equal and sustainable societies. Econ Labour Relat Rev 31(2):133-157. https://doi. org/10.1177/1035304620927107

WEDO. (2016). Infographic: gender and climate change-WEDO. https://wedo.org/gender-climate-infog raphic/. Accessed 5 Nov 2020 
Wisner B, Blaikie P, Cannon T, Davis I (2003) At risk: natural hazards, people's vulnerability and disasters. Routledge, New York

World Trade Organization. (2020). The economic impact Of Covid-19 on women in vulnerable sectors and economies information. https://voxeu.org/article/covid-19-and-gender-gaps-latest-evidenceand-lessons-uk. Accessed 8 Nov 2020

\section{Authors and Affiliations}

\section{Mark M. Akrofi ${ }^{1}\left[\right.$. Mudasiru Mahama ${ }^{2}\left[\right.$ - Chinedu M. Nevo ${ }^{3}$}

Mudasiru Mahama

mudasiru50@gmail.com

Chinedu M. Nevo

chinedunevo@gmail.com

1 Institute for the Advanced Study of Sustainability, United Nations University, Tokyo 150-8925, Japan

2 Regional Center for Energy and Environmental Sustainability, University of Energy and Natural Resources, Sunyani, Ghana

3 Institute of Water and Energy Sciences, Pan African University, 13000 Tlemcen, Algeria 